\title{
Fertility, labour force participation and poverty among married women in Nigeria
}

\author{
Mary O. Obiyan ${ }^{1}$, Adeniyi Francis Fagbamigbe ${ }^{2}$, Olufemi M. Adetutu ${ }^{1}$ \& Funmilola F. \\ Oyinlola ${ }^{1}$
}

\author{
'Department of Demography and Social Statistics, Faculty of Social Sciences, \\ Obafemi Awolowo University, Nigeria \\ ${ }^{2}$ Department of Epidemiology \& Medical Statistics, College of Medicine, \\ University of Ibadan, Nigeria \\ maryobiyan@gmail.com; mobiyan@cartafrica.org.
}

\begin{abstract}
Context: Previous studies have established increasing female employment and fertility transition in developed countries and improved social welfare. However, findings on female employment, fertility transition and poverty incidence have shown mixed results in Nigeria. The paper examined critical issues of fertility, female employment and poverty incidence among women of reproductive ages in Nigeria. Specifically, we examined the linkages between fertility, female employment, and household wealth to enrich our understanding of the relationships among characteristics.

Method: We analysed the 2013 Nigeria DHS dataset. The association of fertility, female employment, and poverty incidence was assessed using Chi-square and multinomial logistic regression.

Results: Female employment was positively related to fertility rate and negatively related to household wealth. Other significant predictors of fertility and poverty incidence are age, level of education, religion, and location of residence.

Conclusion: Women participation in Labour force enhance household wealth status but do not necessarily limit fertility. Policies and programmes aimed at fertility reduction and poverty alleviation should focus on formal employment and female education.
\end{abstract}

Keywords: female employment, poverty incidence, demographic dividend, Nigeria.

\section{Introduction}

Nigeria remains one of the top ten most populous nations in the world. As of 2014, Nigeria's population was more than 170 million and seventh most populated country (Gribble, 20I2). The recent round of the Nigeria Demographic and Health Survey (NDHS, 2013) estimated the total fertility rate at 5.5 children per woman (National Population Commission and ICF International 20I4) which is one of the highest total fertility rate per woman in subSaharan Africa and stalled over the long term (Ezeh et al., 2012, United Nations, 2013, Bongaarts, 2003, Shapiro and Gebreselassie, 2009, McNicoll, 20II).

A copious amount of evidence affirms that one of the characteristics of a high populated nation is poor economic growth index such as low wage, chronic poverty, pervasive unemployment and a myriad of other perennial problems (United Nations, 2013, Buhaug and Urdal, 2013). Far more than we probably realise, Nigeria is richly endowed with both human and mineral resources in quantum proportion. The recent statistical rebasing exercise conducted in 2014 revealed Nigeria as the Africa's largest economy with 2013 GDP estimated at US\$509 billion while her economy grows at $6-8 \%$ per annum (pre-rebasing) (Adetula et al., 2014, World Bank, 2014). Despite this impressive economy growth rate, oil-rich Nigeria has been hobbled by a host of demographic and nondemographic phenomena. More importantly, a sizeable number of Nigerians, over $62 \%$ of Nigeria's 170 million people live in extreme poverty (ibid).

Also, a couple of recent studies have established that fertility transition affects the age structure of a population and brings about economic development (Bloom et al., 2007, Bloom et al., 2009). That is a country with rapidly declining fertility is accompanied by changes in the ratio between the economically active population and dependent population whereby the working population creates an economic support ratio resulting in demographic bonus paving the way for other non-demographic policies to achieve demographic dividend. However, in a number of countries in sub-Saharan Africa including Nigeria, fertility decline has been stalled or receeded (Lawanson, 2008, Garenne, 2010, Mberu and Reed, 
2014). In a corresponding manner, fertility reduction increases the ratio of working-age population lowering the youth dependency ratio. The combination of these effects implies an increase in per capita income of such population.

On the heels of demographic change and development issues, the Sustainable Development Goals (SDGs) which suceeded the Millenium Development Goals (MDG) addressed issues of demographic changes and development (Kates et al., 2005). The SDG 5 aimed to ensure gender equality through the empowerment of all women and girls. It also incorporates other pertinent issues such as access to sexual and reproductive health, recognise the value of unpaid domestic care work, end discrimination, violence and other harmful practices and participation in decision making (Sachs, 2012, Kates et al., 2005). Studies have accertained that there is a relationship between female participation in the labour market and fertility behaviour (Adebiyi and Onifade, 2014, FADAYOMI and Olurinola, 2014, Stycos and Weller, 1967) while others have established a link between a woman's fertility behaviour and ability to engage in either paid or unpaid labour (Sackey, 2005, Lam and Duryea, 1999, Hilgeman and Butts, 2004, Halli and Rao, 1986).

More importantly, the number of these studies from developed and developing countries have shown increasing women participation in the labour force (World Bank, 2014, Lim, 2002, Lawanson, 2008). These prior studies have unambiguously established, especially from the industrialised world, the increasing female labour force participation is linked to fertility transition (Snopkowski and Kaplan, 2014, Balbo et al., 2013, Guetto et al., 2015). Women in this context forgo childbearing efforts if subjective gains from childbearing would not override opportunity cost (Easterlin, 1975, Balbo et al., 2013, Galor, 2012, Snopkowski and Kaplan, 2014) unlike in developing countries especially Nigeria where women have reportedly high fertility rates (between 4 and 7 children per woman) and accompanying high labour force participation (Lawanson, 2008, Adebiyi and Onifade, 2014, Adedini, 2014).

Lending credence to this stance, Becker's pioneering work on fertility based on economic theory (Becker, 1960), many studies have revealed there is a relationship between fertility and labour force decision (Bick, 2015, Lee and Lee, 20I4). Yet, studies on effects of fertility on female employment have yielded mixed results, especially in poor countries(Adedini, 2014, Lawanson, 2008). In addition to this, the traditional African setting where women have had the enormous tasks of childbearing and rearing as well as handling household chores have to a large extent limit labour force participation compared to men(Angrist and Evans, 1996). On the contrary, this stylized fact hitherto evident in developing countries settings has been waning in contemporary demographic researches. An enormous body of empirical literature has shown contradictory findings on "wealth flow" from parents to children and lends credence to the "second demographic transition theory" from hitherto oldfashioned values and beliefs to a new set of worldview and attitudes which emphasise selffulfillment and self-actualization (Lesthaeghe and Neidert, 2006, Brewster and Rindfuss, 2000).

Further, the emergence of the industrialized and global market has created ample spaces for women at different cadres and sectors especially in less developed countries, of which Nigeria is one. Similarly, another contributing factor to women's participation in labour force is the emergence of new household structures such as female headed household whereby women, as the primary breadwinner actively engages in the labour market both in formal and informal sectors to meet the arising family needs (Obiyan and Ogunjuyigbe, 2008, FADAYOMI and Olurinola, 20I4). All this is couched in the inevitable eclipse of the second demographic transition all over the world.

What motivated this study is the divergent of evidence from a number of studies in developing countries including Nigeria between female employment and fertility rate which negates the stylized relationship explained in an earlier study (Mberu and Reed, 2014, Nigeria. National Planning Commission National Economic Empowerment Development Strategy ( NEEDS), 2007). That is, the higher the fertility, the lower women's chances of participation in the labour force and the higher their vulnerability to poverty (Gaddis and Klasen, 2014, Babalola and Akor, 2013). High fertility increases the opportunity costs to a woman. Since women spend most of their time caring for the child especially immediately after childbirth, they have less time to dedicate to paid employment either inside or outside the home (Porter and King, 20I2). High fertility strains the family's budget because of too many dependents which reduce the resources to feed, educate and to provide adequate health care. Thus, many children suffer from malnutrition and infant or child mortality.

Studies have been carried out extensively, mostly in both developed and developing countries on the existing relationship between fertility and economic activity of a woman. The effect of fertility on the participation rate of a woman in the labour force cannot be underestimated. While some studies (Adebiyi and Onifade, 2014, Ahmed et al., 2010) revealed that labour force participation reduces the 
fertility of women, some others showed that fertility has not much impact on labour force participation especially for those who joined after the birth of their first child due to child care services. However, the existing relationship between fertility, labour force participation and poverty of women in sub-Saharan Africa countries, most especially in Nigeria have largely been overlooked or under-researched.

Therefore, this study fills research opacity by exploring in detail, the association between the variables (fertility, labour force participation and poverty), enhances our understanding and generate new insights on the causal relationships among the variables beyond extant studies in Nigeria.

Against the above evidence that an increase in women's labour force participation causes a downward shift in their corresponding fertility, the International Labour Organisation (ILO) recently stated the labour force participation of women in Nigeria had increased from $34.1 \%$ in 1990 to 42.45 in 2014 (World Bank, 2016). On the other hand, the total fertility rate (TFR) of women within the country during the same defined period of 1990 (6.0) and 2014 (5.5) showed little or no significant reduction, although there are variations of TFR across the geopolitical zones (National Population Commission and ICF International 20I4). This development has been of great concern to the government, researchers and policy makers especially when efforts are being made towards achieving the SGDs.

Given this current trend of fertility and poverty level among many married working women, the country's process of economic development could be hampered. Hence, the need to carry out an intensive national study to examine the effect of labour force participation on fertility and poverty level of women. This will add to the literature on nexus between female labour force participation, fertility and household poverty in Nigeria. This study is aimed at understanding the relationship between fertility, labour force participation and household poverty level of women in Nigeria using the 2013 NDHS dataset. It examined the effect of socioeconomic and demographic characteristics on fertility and poverty level. The following research questions shall guide the study:

Does female labour force participation
reduce fertility rate?
labour force participation and household poverty?

\section{Data and Methods}

Data from Nigeria Demographic and Health Survey 2013 was used for this study. The DHS is a large household survey from a nationally representative sample. It provides information on respondents' reproductive health history, nutritional status, awareness and use of modern contraceptives, HIV/AIDs, gender violence, child health among many others. The 2013 NDHS used three stage stratified sampling design for the selection of 904 clusters (372 urban and 532 rural) with a representative sample of 45 households from each cluster having a total of successfully interviewed 38,948 eligible respondents.

Operational definitions and measurements were assigned to variables employed in this study. The main predictor variable is labour force participation of women measured as "Work Status" with two categories of 'no' and 'yes' while the outcome variables are "Fertility behaviour" and "Poverty Level". Children ever born (CEB) was used as proxy for fertility behaviour in this study and categorized into three: no child $=$ ' 0 '; I-3 children = 'I'; 4 or more children $=$ ' 2 '. This categorization was done based on the Nigerians population policy of 4 children per woman. The second outcome variable 'poverty level' is measured by household wealth index (poorest, poorer, middle, richer and richest) as obtained from the 20I3 NDHS.

Data were analysed with STATA 13.0, a statistical package. Different levels of analysis, including, univariate, bivariate, and multivariate analysis, were done in the study. The degree of association was shown between socio-demographic factors of respondents and outcome variables using chi-square tests while the multivariate analysis was done to explore the relationship between the explanatory and outcome variables using multinomial regression model. The multinomial regression fits maximum likelihood models with discrete dependent (left-handside) variables when the dependent variable takes on more than two outcomes and the outcomes have no natural ordering. If the dependent variable takes on only two outcomes, estimates are identical to those produced by logistic or logit.

If the dependent variable $y$ has $k$ levels where $k$ is more than 2 , then

$$
P(y=i)=\frac{e^{x \beta^{i}}}{e^{x \beta^{1}}+e^{x \beta^{2}}+e^{x \beta^{3}}+\cdots \ldots+e^{x \beta^{k}}}
$$

where $\mathrm{i}=\mathrm{I}, 2,3 \ldots, \mathrm{k}$

The model is unidentified in the sense that there is more than one solution to the different k. It works by arbitrarily setting one (base outcome) of the $k_{s}$ to zero whereby the remaining coefficients of $k$ will measure the change relative to the chosen group. The coefficients differ from one chosen $k$ to another because they have different interpretations but the predicted probabilities for the $k_{s}$ will be the same. 
Thus, either parameterization will be a solution to the same underlying model.

For instance, setting $x \beta^{i=1}=0$, the equation become

$$
P(y=1)=\frac{1}{1+e^{x \beta^{2}}+e^{x \beta^{3}}+\cdots \ldots+e^{x \beta^{k}}}
$$

The relative probability of $y=2$ relative to base outcome $y=1$ is given by which is otherwise known as the relative risk so if it is assumed that $X$ and $\beta$ are vectors equal to covariates and their coefficients respectively. The ratio of the relative risk for a oneunit change in $x i$ is then Thus, the exponentiated value of a coefficient is the relative-risk ratio for a one-unit change in the corresponding variable (risk is measured as the risk of the outcome relative to the base outcome. Furthermore, four models will be employed in the multivariate analysis.

Model I: the effect of labour force participation on poverty level

Model II: the effect of labour force participation on fertility level

Model III: adjusted labour force on poverty level; and

Model IV; adjusted labour force on fertility level.

In all the analysis, the significance level was $5 \%$.

\section{Study's Hypotheses}

$>$ Female labour force leads to higher opportunity costs of time, leading to higher contraceptive use and lower fertility rate

$>$ Female labour force participation increases household wealth

\section{Results}

\section{Descriptive results}

In this sub-section, we present a discussion of the descriptive evidence on fertility and household to provide a foundation for the quantitative results. The 2013 NDHS final report makes a very rich presentation of the underlying factors of fertility in Nigeria (National Population Commission and ICF International 20I4). In this section, we therefore only highlight the descriptive evidence germane to the current study, as summarized in Table I.

The summary is generated using the sample weights implying that they are nationally representative and are consistent with those in the 20 I 3 NDHS report. Table I showed the percentage distribution of women's socio-demographic factors. The results showed a higher proportion of women aged 15-24 and 25-34 (37\% and 32\%, respectively) relative to women aged $35-44$ and 45 years or more ( $21 \%$ and $8.7 \%$, respectively). The results show more percentage of educated women compared with the uneducated ( $45 \%$ vs. $38 \%$, respectively).

Regarding women's work status, nearly a twothird was currently working at the time of the survey relative to the unwaged (38\%). The findings of the analyses of the 20I3 NDHS show that most women in Nigeria participate in the labour force. The results further showed an overwhelming proportion of women living with their spouses (7I\%) while (20\%) are unmarried. Half of the women are Islamic faithful, $46 \%$ are Christians while a handful belongs to another religious sect. The findings from this study show the majority of women are relatively poor.

Women's wealth index showed even distribution across the categories of wealth index, each averages one-fifth of the total (poorest, poorer, middle, richer and richest). By region, the findings showed a third of the women are from the North-West geopolitical zone while other geo-political zones average 14\% of the total. Additionally, the finding revealed that the majority of women had at least 4 children. One-third is nulliparous and $32 \%$ had between I and 3 children. These results support the findings that fertility is on the high side in Nigeria.

Table I: Percent Distribution of Respondents Background Characteristics, NDHS 2013

\begin{tabular}{lllc}
\hline Background Characteristics & Number & Percent (\%) & Mean \\
\hline Age Group & & & 28.80 \\
$15-24$ & 14,576 & 37.43 & \\
$25-34$ & 12,612 & 32.38 & 21.41 \\
$35-44$ & 8,338 & 8.79 & \\
$45+$ & 3,422 & 37.82 \\
\hline Educational Level & & 17.29 \\
No Education & 14,729 & 44.89 \\
Primary Education & 6,734 & & \\
Secondary Education & 17,485 & 38.23 \\
\hline Working Status & & 61.77 \\
Not Working & 14,888 & \\
Working & 24,060 & & \\
\hline
\end{tabular}




\begin{tabular}{lll}
\hline Marital Status & 9,326 & 23.94 \\
Not Married & 27,830 & 71.45 \\
Living Together & 1,793 & 4.60 \\
Others & 18,237 & 46.82 \\
\hline Religion & 20,149 & 51.73 \\
Christianity & 361 & 1.44 \\
Islam & & \\
Others & 7,132 & 18.31 \\
\hline Wealth Index & 7,428 & 19.07 \\
Poorest & 7,486 & 19.22 \\
Poorer & 7,992 & 20.52 \\
Middle & 8,910 & 22.88 \\
Richer & & \\
Richest & 5,572 & 14.31 \\
\hline Regions & 5,766 & 14.80 \\
North Central & 11,877 & 30.49 \\
North East & 4,476 & 11.49 \\
North West & 4,942 & 12.69 \\
South East & 6,314 & 16.21 \\
South South & & \\
South West & 11,333 & 29.10 \\
\hline & 12,491 & 32.07 \\
CEB & 15,124 & 38.83 \\
0 & & \\
I-3 & & 3.06 \\
$4+$ & & \\
\hline
\end{tabular}

Relationship between household wealth and women socio-demographic characteristics

In Table 2, we present the association between wealth status and other control variables. The results showed age is significantly associated with wealth quintile $(p<0.05)$. As would be expected, increasing age of women places them on higher wealth ladder. The results show $36 \%$ of women aged $25-34$ years are richer than those aged 15-24 years (34\%). However, the positive relationship between age and wealth index peaked at age 25-34 and declined thereafter for older women aged 35 and above. Regarding education, the results showed a significant relationship with wealth status $(p<0.05)$. Increasing women's education places women of higher wealth status. This confirms previous findings in this study. Women with secondary education or higher are better-off the uneducated ones $(87 \%$ vs.3.3\%, respectively).

The analysis also showed that work status is a predictor of wealth quintile and children ever born $(p<0.05)$. The percentage distribution of women's wealth index increases with their work status. That is, those working are better-off the non-working women with respect to wealth status. For richest wealth quintile, percentage distribution of women working is higher than non-working (64\% vs. $36 \%$ respectively). This finding is in contrast to the presumed hypothesis of chronic poverty even among the working class. Place of residence is also significant with wealth index $(p<0.05)$. Women resident in the urban area is better-off on the wealth status scale than their rural counterparts $(87 \%$ vs. $13 \%$ respectively). Region of residence is a predictor of wealth quintile $(p<0.05)$. Women from the southwest are more in the richest category (37\%), SouthSouth (19\%) and south east (15\%). The proportions in the Northern zones for rich women are lower. A substantial proportion of married women belong to richest wealth category $(60 \%)$, in contrast, $36 \%$ in richest category are unmarried.

Moreover, religion is also associated with wealth index $(p<0.05)$. The Christian faithful is economically better-off than Islamic faithful. Of the women from richest households, $72 \%$ are Christians while $27 \%$ are of Islamic religion. 
Table 2: Percent Distribution of Household Wealth and women's Socio-demographic characteristics

\begin{tabular}{|c|c|c|c|c|c|}
\hline Socio-demographic factors & $\begin{array}{l}\text { Wealth } \\
\text { Poores }\end{array}$ & $\begin{array}{l}\text { Quintile } \\
\text { Poorer }\end{array}$ & Middle & Richer & Richest \\
\hline $\begin{array}{l}\text { Age Group } \\
\text { I5-24 } \\
25-34 \\
35-44 \\
45+\end{array}$ & $\begin{array}{l}P \text { value } \\
33.83 \\
32.28 \\
23.53 \\
10.36\end{array}$ & $\begin{array}{c}0.000 \\
39.26 \\
31.46 \\
19.92 \\
9.36\end{array}$ & $\begin{array}{r}40.71 \\
29.69 \\
20.47 \\
9.13\end{array}$ & $\begin{array}{r}39.23 \\
31.35 \\
20.65 \\
8.77\end{array}$ & $\begin{array}{r}34.39 \\
36.42 \\
22.43 \\
6.77\end{array}$ \\
\hline $\begin{array}{l}\text { Education } \\
\text { None } \\
\text { Primary } \\
\text { Secondary and Higher }\end{array}$ & $\begin{array}{l}P \text { value } \\
87.28 \\
9.13 \\
3.59\end{array}$ & $\begin{array}{r}0.000 \\
61.52 \\
21.09 \\
7.39\end{array}$ & $\begin{array}{l}32.79 \\
26.19 \\
41.02\end{array}$ & $\begin{array}{l}14.83 \\
21.40 \\
63.76\end{array}$ & $\begin{array}{r}3.30 \\
9.48 \\
87.22\end{array}$ \\
\hline $\begin{array}{l}\text { Currently Working } \\
\text { No } \\
\text { Yes }\end{array}$ & $\begin{array}{l}P \text { value } \\
44.17 \\
55.83\end{array}$ & $\begin{array}{c}0.000 \\
38.45 \\
61.55\end{array}$ & $\begin{array}{l}37.82 \\
62.18\end{array}$ & $\begin{array}{l}35.63 \\
64.37\end{array}$ & $\begin{array}{l}35.94 \\
64.06\end{array}$ \\
\hline $\begin{array}{l}\text { Place of Residence } \\
\text { Urban } \\
\text { Rural }\end{array}$ & $\begin{array}{l}P \text { value } \\
5.76 \\
94.24\end{array}$ & $\begin{array}{l}0.000 \\
13.02 \\
86.98\end{array}$ & $\begin{array}{l}32.44 \\
67.56\end{array}$ & $\begin{array}{l}61.12 \\
38.88\end{array}$ & $\begin{array}{l}86.68 \\
13.32\end{array}$ \\
\hline $\begin{array}{l}\text { Marital Status } \\
\text { Not Married } \\
\text { Married / Living Together } \\
\text { Others }\end{array}$ & $\begin{array}{l}\text { P value } \\
7.45 \\
90.07 \\
2.48\end{array}$ & $\begin{array}{c}0.000 \\
14.68 \\
80.59 \\
4.73\end{array}$ & $\begin{array}{r}26.73 \\
66.56 \\
6.71\end{array}$ & $\begin{array}{r}31.48 \\
63.09 \\
5.43\end{array}$ & $\begin{array}{r}35.77 \\
60.55 \\
3.68\end{array}$ \\
\hline $\begin{array}{l}\text { Religion } \\
\text { Christianity } \\
\text { Islam } \\
\text { Others }\end{array}$ & $\begin{array}{l}P \text { value } \\
9.47 \\
88.37 \\
2.15\end{array}$ & $\begin{array}{r}0.000 \\
32.96 \\
65.15 \\
1.89\end{array}$ & $\begin{array}{r}53.04 \\
45.28 \\
1.68\end{array}$ & $\begin{array}{r}58.67 \\
40.25 \\
1.08\end{array}$ & $\begin{array}{r}72.43 \\
26.95 \\
0.62\end{array}$ \\
\hline $\begin{array}{l}\text { Regions } \\
\text { North Central } \\
\text { North East } \\
\text { North West } \\
\text { South East } \\
\text { South South } \\
\text { South West }\end{array}$ & $\begin{array}{l}P \text { value } \\
7.95 \\
31.18 \\
56.59 \\
2.66 \\
0.30 \\
1.33\end{array}$ & $\begin{array}{r}0.000 \\
14.96 \\
20.07 \\
46.96 \\
7.40 \\
5.64 \\
4.96\end{array}$ & $\begin{array}{r}23.05 \\
11.84 \\
24.94 \\
14.88 \\
15.98 \\
9.32\end{array}$ & $\begin{array}{r}14.82 \\
8.31 \\
18.29 \\
16.18 \\
19.84 \\
22.56\end{array}$ & $\begin{array}{r}11.04 \\
5.62 \\
11.49 \\
14.93 \\
19.31 \\
37.61\end{array}$ \\
\hline
\end{tabular}

Relationship between children ever born and women socio-demographic characteristics

We explored the association between children ever born and respondents' characteristics as shown in Table 3. The results showed that number of children ever born increases with age. While women $36 \%$ of women aged $25-34$ had 4 or more children, $2.1 \%$ of those aged 15-24 had at least 4 children, however, the pattern changed for older women with a reduced children ever born (3.3\%). As regards education, the results showed a significant relationship with children ever born $(p<0.05)$. More than half uneducated women had 4 children or more relative to those of secondary education or higher (22\%). This is because a number of studies have unambiguously established that increasing female education leads to higher participation in labour market and in turn reduced fertility rates.
Furthermore, we found work status as a predictor of children ever born $(p<0.05)$. A positive relationship exists between working women and children ever born. The results showed a higher percentage of women working who had at least 4 children relative to those not working ( $78 \%$ vs. $22 \%$ respectively). Importantly, this is one of the overriding motivations for this study. In fact, it confirms the hypothesis and shows where our finding sits in the body of literature given the confounding results in Nigerian context as in other developing countries. Place of residence is also significant with children ever born $(p<0.05)$. Women in rural area had more children than those residents in urban area. More than two-thirds of women in the rural area had at least 4 children relative to those in the urban area (35\%). Similarly, region of residence is a predictor of children ever born $(p<0.05)$ with higher rates in the northern regions compared with the southern regions. 
Marital status is statistically associated with children ever born $(p<0.05)$. Higher proportion of married women had at least 4 children relative to the unmarried ( $94 \%$ vs $0.2 \%$ ). The finding also confirms the work of Bongaarts that higher proportion of women in marriage is one of the proximate determinants of fertility. Religion is also associated with children ever born $(p<0.05)$. The Muslim women have higher number of children ever born than Christians (61\% vs. $37 \%$ respectively).

Table 3: Percent distribution of children ever born by respondents'socio-demographic characterictics

\begin{tabular}{|c|c|c|c|}
\hline \multirow[t]{2}{*}{ Socio-demographic factors } & \multicolumn{3}{|c|}{$\begin{array}{l}\text { Fertility Behaviour } \\
\text { Children Ever Born }\end{array}$} \\
\hline & 0 & $1-3$ & $4+$ \\
\hline Age Group & \multicolumn{3}{|c|}{$P$ value: 0.000} \\
\hline $15-24$ & 80.31 & 41.28 & 2.11 \\
\hline $25-34$ & 15.54 & 42.73 & 36.45 \\
\hline $35-44$ & 3.24 & 12.60 & 42.30 \\
\hline $45+$ & 0.91 & 3.39 & 19.14 \\
\hline Education & \multicolumn{3}{|c|}{$P$ value: 0.000} \\
\hline None & 17.73 & 37.14 & 53.43 \\
\hline Primary & 9.88 & 16.35 & 23.62 \\
\hline Secondary and Higher & 72.39 & 46.51 & 22.96 \\
\hline Currently Working & \multicolumn{3}{|c|}{$P$ value: 0.000} \\
\hline No & 62.97 & 35.02 & 22.33 \\
\hline Yes & 37.03 & 64.98 & 77.67 \\
\hline Place of Residence & \multicolumn{3}{|c|}{$P$ value: 0.000} \\
\hline Urban & 53.03 & 41.32 & 34.67 \\
\hline Rural & 46.97 & 58.68 & 65.33 \\
\hline Marital Status & \multicolumn{3}{|c|}{$P$ value: 0.000} \\
\hline Not Married & 76.84 & 4.80 & 0.12 \\
\hline Married / Living Together & 21.85 & 89.72 & 93.54 \\
\hline Others & 1.31 & 5.48 & 6.34 \\
\hline Religion & \multicolumn{3}{|c|}{$P$ value: 0.000} \\
\hline Christianity & 59.61 & 46.59 & 37.43 \\
\hline Islam & 39.35 & 52.03 & 60.77 \\
\hline Others & 1.04 & 1.38 & 1.80 \\
\hline Regions & \multicolumn{3}{|c|}{$P$ value: 0.000} \\
\hline North Central & 15.29 & 14.69 & 13.26 \\
\hline North East & 12.18 & 15.24 & 16.42 \\
\hline North West & 22.29 & 28.72 & 38.10 \\
\hline South East & 16.75 & 9.40 & 9.28 \\
\hline South South & $16.4 \mid$ & 12.76 & 9.84 \\
\hline South West & 17.08 & 19.19 & 13.10 \\
\hline
\end{tabular}

Relationship between Labour Force Participation on Poverty Level

The outcome of multinomial logistic regression of poverty level on women's labour force participation showed that women working are $26 \%$ more likely to be poorer relative to non-working women instead of being in the poorest wealth category. In like manner, working women are 1.28 times more likely to be in the middle-income category compared with those not working, instead of being in the poorest http://aps.journals.ac.za household wealth category. Those who are working also have 1.32 odds of being richer than the nonworking, instead of being in the poorest wealth category. A similar result was estimated for the richest category (Not shown in the tables).

\section{Results from Multivariate Analysis}

Table 4 shows the multivariate relationship between socio-demographic factors and wealth status. The results revealed women working are $1 \%$ more likely 
of being the poorer compared with non-working women, instead of being in the poorest wealth quintile. Working women are I percent less likely to be in the middle-income wealth category relative to non-working women, instead of being among the poorest wealth quintile. The results further showed that working women are $4 \%$ less likely to be in the richer wealth category relative to non-working women, rather than being in the poorest category. Similarly, the findings showed that working women are $18 \%$ less likely to in the richest wealth category relative to non-working women, instead of being in the poorest wealth category. As regards age, the results showed a significant relationship with wealth quintile. Women aged $25-34$ have $23 \%$ relative risk of been in the poorer wealth category compared with those aged 15-24, rather than being in the poorest wealth category. The results further showed women aged $25-34$ are $4 \%$ more likely to be in the middle-income category relative to those aged I5-24, rather than being in the poorest category. Women aged 35-44 are almost 3 times more likely to be in the richest wealth category relative to those aged I524 , instead of being in the poorest category.

On the ages of respondents, there were higher odds of increasing wealth status with increasing ages. Concerning level of education, the findings showed women with only primary school education are $98 \%$ more likely to be in the poorer wealth category relative to the uneducated, instead of being in the poorest category, those having secondary education or higher are almost 4 times more likely to in the poorer wealth category compared with noneducated women, instead of being in the poorest category. The results further showed women of secondary school education or higher to be 60 times more likely to be richer than the uneducated rather than being in the poorest wealth category. In addition to this, women with primary education are 9 times more likely to be in the richest wealth category relative to the uneducated rather than being in the poorest category. The results showed the increasing wealth of women as they move up the educational ladder. Regarding marital status, married women/living together with a spouse is $34 \%$ more likely to be poorer relative to the unmarried women, instead of being in the poorest wealth category.

In the same vein, married women are $50 \%$ more likely to be richer than the unmarried women rather than being in the poorest wealth category. Invariably, being married increases wealth status of women. The results showed Islamic faithful are $37 \%$ less likely to be poorer relative to Christians, instead of being in the poorest wealth category. The Islamic worshippers are also 14\% more likely to be in the richest wealth category relative to the Christians instead of being in the poorest wealth category. With a place of residence, the results revealed rural women are $56 \%$ less likely to be in the poorer wealth category relative to the urban women, rather than being in the poorest wealth status. Similarly, women in the rural area are $95 \%$ less likely to be in the richest wealth group relative to the urban women instead of being in the poorest wealth category. Simply put, urban women are better-off with respect to wealth status. By region, the results showed women from the South-South are 4 times more likely to be in the poorer wealth category relative to the women from North Central, rather than being in the poorest wealth status. South-West and South-South women are 3 and 12 times more likely to be in the richest wealth category relative to the women from North Central instead of being in the poorest wealth status. Women from the Southern dichotomy are richer than the Northern axis.

Table 4: Multinomial regression of respondents' wealth status on socio-demographic factors

\begin{tabular}{|c|c|c|c|c|}
\hline Socio-demographic factors & $\begin{array}{l}\text { Poorer } \\
\text { RRR }(95 \% \quad \mathrm{Cl}) \quad \mathrm{p} \text { - } \\
\text { value }\end{array}$ & $\begin{array}{l}\text { Middle } \\
\text { RRR }(95 \% \mathrm{Cl}) \text { p-value }\end{array}$ & $\begin{array}{l}\text { Richer } \\
\text { RRR }(95 \% \mathrm{Cl}) \quad \mathrm{p} \text {-value }\end{array}$ & $\begin{array}{l}\text { Richest } \\
\text { RRR }(95 \% \mathrm{Cl}) \text { p-value }\end{array}$ \\
\hline \multicolumn{5}{|l|}{ Work Status } \\
\hline No & 1.00 & 1.00 & 1.00 & 1.00 \\
\hline Yes & $1.01(1.02-1.19)^{*}$ & $0.99(0.91-1.08)$ & $0.96(0.87-1.06)$ & $0.82(0.73-0.91)^{* * * *}$ \\
\hline \multicolumn{5}{|l|}{ Age Group } \\
\hline $15-24$ & 1.00 & 1.00 & 1.00 & 1.00 \\
\hline $25-34$ & $0.87(0.79-0.95)^{* * *}$ & $\mathrm{I} .04(0.93-\mathrm{I} .15)$ & $\mathrm{I} .4 \mathrm{I}(\mathrm{I} .25-\mathrm{I} .59)^{* * * *}$ & $2.64(2.30-3.02)^{* * * *}$ \\
\hline $35-44$ & $0.74(0.66-0.8 \mathrm{I})^{* * * *}$ & $0.96(0.86-1.09)$ & $1.42(1.24-1.62)^{* * *}$ & $2.96(2.53-3.46)^{* * *}$ \\
\hline $45+$ & $0.77(0.68-0.88)^{* * * *}$ & $\mathrm{I} .03(0.88-\mathrm{I} .19)$ & $1.72(1.45-2.04)^{* * * *}$ & $3.19(2.61-3.90)^{* * * *}$ \\
\hline \multicolumn{5}{|l|}{ Level of Education } \\
\hline None & 1.00 & 1.00 & 1.00 & 1.00 \\
\hline Primary & $1.98(\mathrm{I} .77-2.2 \mathrm{I})^{* * * *}$ & $3.76(3.34-4.22)^{* * * *}$ & $6.43(5.63-7.35)^{* * * *}$ & $9.81(8.12-11.83)^{* * * *}$ \\
\hline Secondary and Higher & $3.94(3.34-4.64)^{* * * *}$ & $15.13(12.82-17.86)^{* * * *}$ & $60.60(50.82-72.26)^{* * * *}$ & $296.67(239.86-66.94)^{* * * * *}$ \\
\hline
\end{tabular}




\begin{tabular}{|c|c|c|c|c|}
\hline \multicolumn{5}{|l|}{ Marital Status } \\
\hline Not Married & 1.00 & 1.00 & 1.00 & 1.00 \\
\hline Married / Living Together & $\mathrm{I} .34(\mathrm{I} .16-\mathrm{I} .54)^{* * * *}$ & $1.39(1.20-1.6 \mathrm{I})^{* * * *}$ & $1.50(1.28-1.76)^{* * * *}$ & $1.29(1.09-1.53)^{* *}$ \\
\hline Others & $\mathrm{I} .80(\mathrm{I} .42-2.30)^{* * * *}$ & $2.17(1.68-2.79)^{* * * *}$ & $2.05(1.56-2.68)^{* * * *}$ & I.34 (0.99-I.80) \\
\hline \multicolumn{5}{|l|}{ Religion } \\
\hline Christianity & 1.00 & 1.00 & 1.00 & 1.00 \\
\hline Islam & $0.63(0.56-0.72)^{* * * *}$ & I.I $7(\mathrm{I} .02-\mathrm{I} .34)^{*}$ & I.68 $(\mathrm{I} .45-\mathrm{I} .94)^{* * * *}$ & I.I 4 (0.98-I.33) \\
\hline Others & $0.47(0.37-0.62)^{* * *}$ & $0.44(0.32-0.60)^{* * *}$ & $0.36(0.25-0.52)^{* * * *}$ & $0.30(0.19-0.47)^{* * * *}$ \\
\hline \multicolumn{5}{|l|}{ Place of Residence } \\
\hline Urban & 1.00 & Ref Cat & Ref Cat & Ref Cat \\
\hline Rural & $0.44(0.39-0.50)^{* * * *}$ & $0.14(0.12-0.16)^{* * *}$ & $0.05(0.04-0.05)^{* * * *}$ & $0.01(0.01-0.01)^{* * * *}$ \\
\hline \multicolumn{5}{|l|}{ Region } \\
\hline North Central & Ref Cat & Ref Cat & Ref Cat & Ref Cat \\
\hline North East & $0.4 \mathrm{I}(0.36-0.47)^{* * * *}$ & $0.13(0.11-0.14)^{* * *}$ & $0.10(0.09-0.12)^{* * *}$ & $0.07(0.06-0.09)^{* * *}$ \\
\hline North West & $0.5 \mathrm{I}(0.45-0.59)^{* * * *}$ & $0.14(0.12-0.16)^{* * * *}$ & $0.14(0.12-0.16)^{* * * *}$ & $0.09(0.08-0.11)^{* * * *}$ \\
\hline South East & $0.45(0.36-0.55)^{* * * *}$ & $0.31(0.25-0.38)^{* * * *}$ & $0.33(0.27-0.4 \mathrm{I})^{* * * *}$ & $0.15(0.12-0.19)$ \\
\hline South South & $4.35(2.96-6.38)^{* * * *}$ & $7.17(4.90-10.49)^{* * * *}$ & $14.59(9.93-2 \mid .42)^{* * * *}$ & I $2.47(8.44-\mid 8.42) * * *$ \\
\hline South West & $1.4(1.08-1.84)^{*}$ & $1.34(1.02-1.74)^{*}$ & $3.02(2.31-3.94)^{* *}$ & $2.99(2.27-3.92)^{* * * *}$ \\
\hline
\end{tabular}

${ }^{+}$Poorest Wealth Quintile is the base category compared with other categories

The multinomial logistic regression of women socioeconomic status and fertility behaviour is presented in Table 5. The results showed working women are $85 \%$ less likely to have between I and 3 children relative to non-working women, instead of being childless. In addition, working women are $47 \%$ less likely to have 4 or more children relative to nonworking women, rather than being childless. The results revealed household wealth is statistically associated with children ever born. Poorer women are $24 \%$ less likely to have between I and 3 children relative to poorest women, rather than having no children. Similarly, poorer women are also $39 \%$ less likely to have 4 or more children compared with poorest women, instead of being a childless woman. For those in the middle wealth category, the results showed $47 \%$ fewer odds of having between I and 3 children compared with poorest women, instead of being childless. Almost $61 \%$ are less likely of having 4 or more children relative to poorest women, instead of being childless. The richest are $54 \%$ less likely to have between $I$ and 3 children relative to poorest women, instead of being childless.

Women that were currently working were $24 \%$ less likely to have I and 3 children relative to nonworking women, instead of being childless. In the same token, women working are almost 3 times more likely to have 4 or more children relative to non-working women, instead of being childless. The results showed clearly that working women have higher children ever born. With regard to age group, women aged 25-34 are almost three times more likely to have between $I$ and 3 children relative to women aged 15-124, rather than being a childless mother. In addition, women aged 45 years or above are 195 times more likely to have 4 children or more relative to those aged 15-24 rather than being childless woman. The analysis showed the older the women, the higher the odds of having more children.

Concerning women's education, the results showed women of secondary school education are $20 \%$ less likely to have between I and 3 children relative to the uneducated instead of being a childless woman. Also, women with secondary education or higher are $71 \%$ less likely to have 4 children or more relative to the uneducated women, rather than being a childless woman. By implication, education has a negative relationship with children ever born. The results further showed that married women are 60 times more likely to have between I and 3 children relative to the unmarried, instead of being a childless mother. Married women are also 7/3 times more likely to have 4 children or more relative to unmarried women, rather than being childless. Expectedly, married women had more birth than the unmarried. Regarding religion, Islamic faithful is I times more likely to have 4 or more children compared with the Christians, rather than being childless. As discussed earlier, a resident of the urban area is less likely to have children as the rural folks. The analysis showed that rural women are almost 2 times more likely to have between I and 3 children relative to the urban women, instead of being childless. As regards region, the results showed women from the Northern geopolitical zones are more likely to have given birth to more children than those from the Southern part. The results revealed women from the North East are 2 times more likely to have 4 children or more relative to those from the North Central, instead of being childless. However, multicollinearity affected the patterns of the results. The results surprisingly showed women from the South-South are two times more likely to have 4 or more children compared with those from North Central, rather than being childless. 
Table 5: Multinomial regression of respondents' fertility behaviour on socio-demographic factors

\begin{tabular}{|c|c|c|}
\hline \multirow[b]{2}{*}{ Socio-demographic factors } & \multicolumn{2}{|c|}{ Fertility Behaviour (CEB) } \\
\hline & $\begin{array}{l}\text { I-3 } \\
\text { RRR }(95 \% \mathrm{Cl}) \text { p-value }\end{array}$ & $\begin{array}{l}4+ \\
\operatorname{RRR}(95 \% \mathrm{Cl}) \quad \mathrm{p} \text {-value }\end{array}$ \\
\hline $\begin{array}{l}\text { Socio-Economic Status } \\
\text { No } \\
\text { Yes }\end{array}$ & $\begin{array}{l}\operatorname{Ref} \\
0.15(0.14-0.16)^{* * *}\end{array}$ & $\begin{array}{l}\operatorname{Ref} \\
0.53(0.50-0.55)^{* * *}\end{array}$ \\
\hline $\begin{array}{l}\text { Household Wealth } \\
\text { Poorest } \\
\text { Poorer } \\
\text { Miiddle } \\
\text { Richer } \\
\text { Richest }\end{array}$ & $\begin{array}{l}\text { Ref } \\
0.76(0.69-0.84)^{* * * *} \\
0.53(0.48-0.58)^{* * *} \\
0.48(0.43-0.52)^{* * * *} \\
0.46(0.42-0.51)^{* * *}\end{array}$ & $\begin{array}{l}\text { Ref } \\
0.61(0.56-0.67)^{* * * *} \\
0.39(0.36-0.43)^{* *} \\
0.29(0.27-0.32)^{* * * *} \\
0.18(0.16-0.20)^{* * * *}\end{array}$ \\
\hline $\begin{array}{l}\text { Work Status } \\
\text { No } \\
\text { Yes }\end{array}$ & $\begin{array}{l}1.00 \\
0.76(0.68-0.85)\end{array}$ & $\begin{array}{l}1.00 \\
2.35(2.13-2.60)^{* * * *}\end{array}$ \\
\hline $\begin{array}{l}\text { Age Group } \\
15-24 \\
25-34 \\
35-44 \\
45+\end{array}$ & $\begin{array}{l}2.54(2.3 \mathrm{I}-2.79)^{* * * *} \\
\mathrm{I} .93(\mathrm{I} .65-2.26)^{* * * *} \\
\mathrm{I} .32(\mathrm{I} .02-\mathrm{I} .69)^{*}\end{array}$ & $\begin{array}{l}56.87(49.10-65.86)^{* * *} \\
217.73(\mid 67.70-282.70) \\
195.49(|6| .9 \mid-236.03)^{* * *}\end{array}$ \\
\hline $\begin{array}{l}\text { Level of Education } \\
\text { None } \\
\text { Primary } \\
\text { Secondary and Higher }\end{array}$ & $\begin{array}{l}\mathrm{I} .23(\mathrm{I} .07-\mathrm{I} .4 \mathrm{I})^{* * *} \\
0.80(0.7 \mathrm{I}-0.9 \mathrm{I})^{* * *}\end{array}$ & $\begin{array}{l}1.21(1.04-1.4 I)^{*} \\
0.29(0.25-0.34)^{* * *}\end{array}$ \\
\hline $\begin{array}{l}\text { Marital Status } \\
\text { Not Married } \\
\text { Married / Living Together } \\
\text { Others }\end{array}$ & $\begin{array}{l}60.37(53.92-67.58)^{* * * *} \\
47.34(38.16-58.74)^{* * *}\end{array}$ & $\begin{array}{l}7|3.5|(451.28-\mid 128.12)^{* * * *} \\
331.03(202.09-542.24)^{* * * *}\end{array}$ \\
\hline $\begin{array}{l}\text { Religion } \\
\text { Christianity } \\
\text { Islam } \\
\text { Others }\end{array}$ & $\begin{array}{l}0.8 \mathrm{I}(0.72-0.92)^{* *} \\
\mathrm{I} .0 \mathrm{I}(0.69-1.48)\end{array}$ & $\begin{array}{l}1.05(0.91-1.22) \\
1.07(0.70-1.64)\end{array}$ \\
\hline $\begin{array}{l}\text { Place of Residence } \\
\text { Urban } \\
\text { Rural }\end{array}$ & $\begin{array}{l}1.00 \\
1.23(1.12-1.34)^{* * *}\end{array}$ & $\begin{array}{l}\text { Ref Cat } \quad 1.00 \\
1.5 \mathrm{I}(1.36-1.68)^{* * *}\end{array}$ \\
\hline $\begin{array}{l}\text { Region } \\
\text { North Central } \\
\text { North East } \\
\text { North West } \\
\text { South East } \\
\text { South South } \\
\text { South West }\end{array}$ & $\begin{array}{l}\text { Ref Cat I.00 } \\
\text { I.00(0.86- I.I5) } \\
0.84(0.73-0.97)^{*} \\
\mathrm{I} .06(0.89-\mathrm{I} .25) \\
\mathrm{I} .85(\mathrm{I} .59-2.16)^{* * *} \\
\mathrm{I} .56(\mathrm{I} .35-\mathrm{I} .83)^{* * *}\end{array}$ & 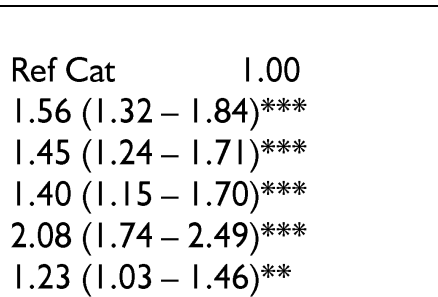 \\
\hline
\end{tabular}

"Women with "no children" is the base category compared with other categories

\section{DISCUSSIONS AND CONCLUSION}

Our paper revealed many salient findings in line with prior studies on women's labour force participation, fertility behaviour and poverty level. While most prior studies on women labour force participation and fertility behaviour in most developing countries have not shown consistent results as to whether being engaged in the labour force inhibits or buffers the propensity to have more children (Balbo et al., 2013, Bernhardt, 1993, Hilgeman and Butts, 2004).
This contradicts the importance of enhancing women's employment as a major driver of fertility transition that paves the way for a demographic window of opportunity that policy makers can take advantage of in realizing the so-called demographic dividend. Unlike the findings of several prior studies (Kalwij, 2000, Sackey, 2005, Adsera, 2004), which established most countries in the advanced stage of socio-economic, development where a negative relationship is confirmed between women's employment status and fertility levels (Porter and 
King, 20I2). Our analyses indicate a contrary result. Our results show higher fertility level among women that are employed.

This may be attributed to tight budget restraints, availability of family support system or child care centers whereby women though employed continually have their desired family size as there are paid (child care centres) or unpaid (family members) support to assist in child care (Porter and King, 20I2, Upadhyay et al., 2014, Del Boca, 2002). This finding also lends credence to the sustained stalled fertility level in Nigeria as in other developing countries in sub-Saharan Africa. Furthermore, the higher fertility level among employed women is in consonance with the result of a study by Adedini (2014) on fertility transition in sub-Saharan Africa. In his study, findings on the level of TFR by employment did not yield a similar pattern in all the selected countries. While the fertility level was constantly higher for the employed women in Rwanda than the unemployed, conversely, findings indicate a consistently lower fertility for the employed in South Africa compared with the unemployed.

Additionally, our findings indicate children ever born consistently reduced with increased levels of education. Results from this study showed that as the level of education increases, the level of fertility reduces as do poverty incidence. This finding is in tandem with the study of Bongaarts (2003) that observed that educational attainment is a key determinant of fertility level, and low levels of education can significantly lead to stalling in fertility transition. Although poverty is chronic in Nigeria, our results showed that women with increasing level of education have reduced fertility and are better-off in household wealth and are more engaged in the labour market. While our results showed higher fertility rates among working women, it did not confirm poorer wealth status among working women. Overall, our study showed that increasing women education generally enhances their wealth status especially among women with high fertility. There is need to empower women with better education as fertility and poverty reduction strategy

In conclusion, the study showed an increase in female employment enhance household wealth status but not necessarily limit fertility. Therefore, policies, programmes and other interventions aimed at fertility reduction and poverty alleviation should factor in quality education for women and encourage formal employment opportunities.

The study revealed Nigeria's women are predominantly young and resident in rural areas, and imply that women have a long reproductive period hence being vulnerable to producing many children, corroborating previous studies.

\section{Strengths and Limitations of study}

This study has a major strength in that it sourced data from a nationally representative source; the 2013 NDHS data set is a robust data that has international appeal for limited sampling design and error. The study has also shown the modest contribution to the study of fertility, female employment and poverty incidence in Nigeria. Although, several studies has examined the relationship between fertility and labour force participation, however, this study has made a huge contribution to the discourse on fertility, labour force and poverty incidence in Nigeria as to the interrelationships among the variables.

On the other hand, this study has its limitations. One, what we used to measure wealth status as used elsewhere including possession of some household materials may not be generalized in every culture. Another is the female employment status. It is interesting to note that questions on occupational categories for women in the 2013 NDHS were not framed on the utilization of labour as there could be conceptual and definitional problems such as time work, job mismatch, time reference and a host of others. However, our result is a modest contribution to the on-going discourse on female employment, fertility level and poverty incidence in Nigeria.

\section{References}

ADEBIYI, O. O. \& ONIFADE, T. A. 20I4. Testing the Relationship between Female Labour Force Participation and Fertility in Nigeria. Mediterranean Journal of Social Sciences, 5, 1322.

ADEDINI, S. A. 20I4. 6 Fertility Transition in SubSaharan Africa. Continuity and Change in SubSaharan African Demography, 97.

ADETULA, V., MIELNICZUK, F., YATES, E., MOSCROP, H., DUNGEL, E., WEHINGER, F., VARISCO, A. E., MORGAN LOCHHEAD, J., LINKLATER, A. \& BRETT, P. 20I4. Nigeria's Rebased Economy and its role in regional and Global Politics. E-International Relations, October, 13.

ADSERA, A. 2004. Changing fertility rates in developed countries. The impact of labor market institutions. Journal of Population Economics, 17, 17-43.

AHMED, S., CREANGA, A. A., GILLESPIE, D. G. \& TSUI, A. O. 20I0. Economic status, education and empowerment: implications for maternal health service utilization in developing countries. PloS one, 5, ell 190.

ANGRIST, J. D. \& EVANS, W. N. 1996. Children and their parents' labor supply: Evidence from exogenous variation in family size. National Bureau of Economic Research. 
BABALOLA, S. J. \& AKOR, M. 2013. An empirical analysis of labour force participation of married women in Adamawa State, Nigeria. Journal of Emerging Trends in Economics and Management Sciences, 4, I.

BALBO, N., BILLARI, F. C. \& MILLS, M. 2013. Fertility in advanced societies: A review of research. European Journal of Population/Revue européenne de Démographie, 29, I-38.

BECKER, G. S. 1960. An economic analysis of fertility. Demographic and economic change in developed countries. Columbia University Press.

BERNHARDT, E. M. 1993. Fertility and employment. European sociological review, 9, 25-42.

BICK, A. 20I5. The quantitative role of child care for female labor force participation and fertility. Journal of the European Economic Association.

BLOOM, D. E., CANNING, D., FINK, G. \& FINLAY, J. E. 2009. Fertility, female labor force participation, and the demographic dividend. Journal of Economic Growth, I4, 79-I0I.

BLOOM, D. E., CANNING, D., MANSFIELD, R. K. \& MOORE, M. 2007. Demographic change, social security systems, and savings. Journal of Monetary Economics, 54, 92-II 4.

BONGAARTS, J. 2003. Completing the fertility transition in the developing world: The role of educational differences and fertility preferences. Population Studies, 57, 32I-335.

BREWSTER, K. L. \& RINDFUSS, R. R. 2000. Fertility and women's employment in industrialized nations. Annual review of sociology, 26, 27I-296.

BUHAUG, H. \& URDAL, H. 20I3. An urbanization bomb? Population growth and social disorder in cities. Global Environmental Change, 23, I-I0.

DEL BOCA, D. 2002. The effect of child care and part time opportunities on participation and fertility decisions in Italy. Journal of Population Economics, I5, 549-573.

EASTERLIN, R. A. 1975. An economic framework for fertility analysis. Studies in family planning, 6, 5463.

EZEH, A. C., BONGAARTS, J. \& MBERU, B. 2012. Global population trends and policy options. The Lancet, 380, I42-I 48.

FADAYOMI, T. \& OLURINOLA, I. 2014. Determinants of Labour Force Participation in Nigeria: The Influence of Household Structure. Journal of Economics, 2, 169-190.

GADDIS, I. \& KLASEN, S. 20I4. Economic development, structural change, and women's labor force participation. Journal of Population Economics, 27, 639-68I.

GALOR, O. 2012. The demographic transition: causes and consequences. Cliometrica, 6, I-28.
GARENNE, M. 20I0. Situations of fertility stall in subSaharan Africa.

GRIBBLE, J. N. 2012. World Population Data Sheet 2012. Washington, DC: Population Reference Bureau.

GUETTO, R., LUIJKX, R. \& SCHERER, S. 2015. Religiosity, gender attitudes and women's labour market participation and fertility decisions in Europe. Acta Sociologica, 58, 155-172.

HALLI, S. S. \& RAO, K. 1986. Dynamics of fertility and labour force participation of Canadian women in 197I and 198I: a cohort approach. Journal of Institute of Economic Research. JSS Institute of Economic Research, 22, I-2I.

HILGEMAN, C. \& BUTTS, C. T. 2004. Family policy, women's employment, and below-replacement fertility in developed countries: A hierarchical Bayesian approach'. Institute for Mathematical Behavioral Sciences.

KALWIJ, A. S. 2000. The effects of female employment status on the presence and number of children. Journal of population economics, 13, 22I-239.

KATES, R. W., PARRIS, T. M. \& LEISEROWITZ, A. A. 2005. What is sustainable development? Goals, indicators, values, and practice. Environment(Washington DC), 47, 8-2I.

LAM, D. \& DURYEA, S. 1999. Effects of schooling on fertility, labor supply, and investments in children, with evidence from Brazil. Journal of Human Resources, 160-192.

LAWANSON, O. I. 2008. Female labour force participation in Nigeria:'Determinants and Trends'. Department of Economics, University of Lagos, Nigeria.

LEE, G. H. \& LEE, S. P. 20|4. Childcare availability, fertility and female labor force participation in Japan. Journal of the Japanese and International Economies, 32, 7I-85.

LESTHAEGHE, R. J. \& NEIDERT, L. 2006. The second demographic transition in the United States: Exception or textbook example? Population and Development Review, 32, 669698.

LIM, L. L. 2002. Female labour-force participation.

MBERU, B. U. \& REED, H. E. 20I4. Understanding subgroup fertility differentials in Nigeria. Population review, 53, 23.

MCNICOLL, G. 20II. Achievers and laggards in demographic transition: A comparison of Indonesia and Nigeria. PoPulation and develoPment review, 37, I9I-214.

NATIONAL POPULATION COMMISSION AND ICF INTERNATIONAL 20I4. Nigeria Demographic and Health Survey 2013, Abuja, 
Nigeria, and Rockville, Maryland, USA: NPC and ICF International.

NIGERIA. NATIONAL PLANNING COMMISSION NATIONAL ECONOMIC EMPOWERMENT DEVELOPMENT STRATEGY ( NEEDS) 2007. National Economic Empowerment and Development Strategy-2: NEEDS-2, National Planning Commission.

OBIYAN, M. O. \& OGUNJUYIGBE, P. O. (eds.) 2008. Household Headship, Household Size and Child Health in South-Western Nigeria Cuvillier Verlag Gottingen.

PORTER, M. \& KING, E. M. 20I2. Fertility and women's labor force participation in developing countries. Mimeo. Department of Economics, University of Oxford.

SACHS, J. D. 2012. From millennium development goals to sustainable development goals. The Lancet, 379, 2206-221I.

SACKEY, H. A. 2005. Female labour force participation in Ghana: The effects of education, African Economic Research Consortium.

SHAPIRO, D. \& GEBRESELASSIE, T. 2009. Fertility transition in sub-Saharan Africa: falling and stalling.
SNOPKOWSKI, K. \& KAPLAN, H. 20I4. A synthetic biosocial model of fertility transition: testing the relative contribution of embodied capital theory, changing cultural norms, and women's labor force participation. American journal of physical anthropology, I54, 322-333.

STYCOS, J. M. \& WELLER, R. H. 1967. Female working roles and fertility. Demography, 4, 210217.

UNITED NATIONS 2013. World Population Prospects: The 2012 Revisioncomprehensive Dataset in Excel, United Nations Publications.

UPADHYAY, U. D., GIPSON, J. D., WITHERS, M., LEWIS, S., CIARALDI, E. J., FRASER, A., HUCHKO, M. J. \& PRATA, N. 20I4. Women's empowerment and fertility: A review of the literature. Social Science \& Medicine, II5, III120.

WORLD BANK 20I4. World Development Report 2015.

WORLD BANK 2016. Labor force, female (\% of total labor force). International Labour Organization, using World Bank population estimates. 